ISSN 2236-0859

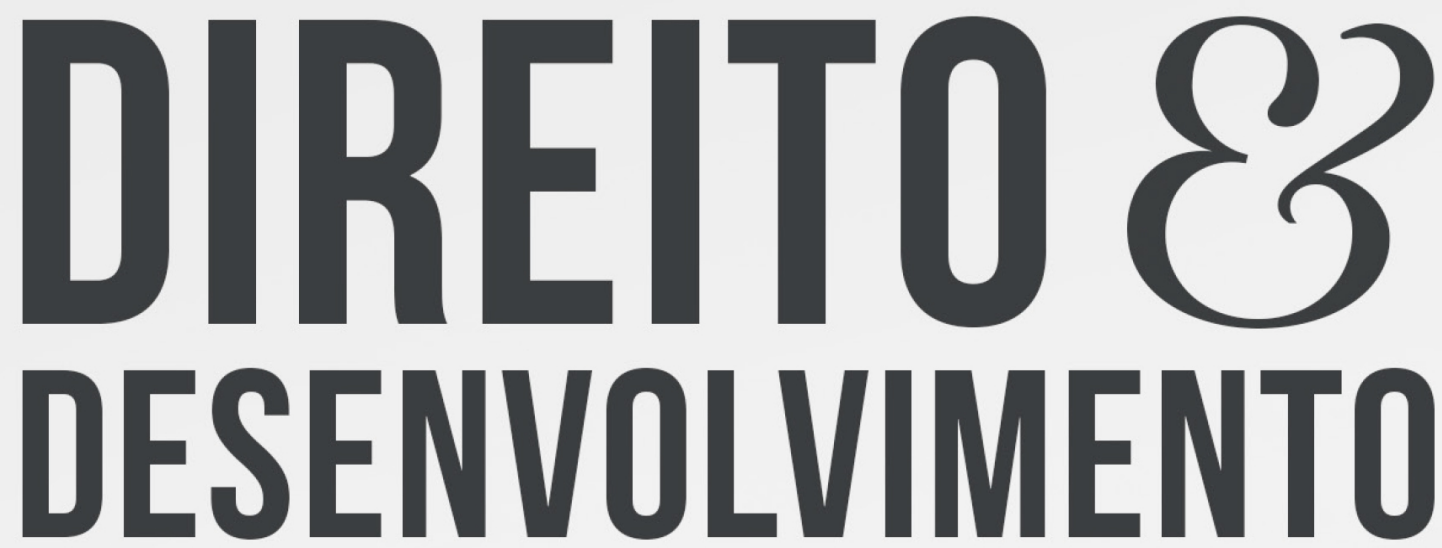

REVISTA DO PROGRAMA DE PÓS-GRADUAÇ̃̃O EM DIREITO MESTRADO EM DIREITO E DESENVOLVIMENTO SUSTENTÁVEL

\title{
EFICÁCIA OU SIMBOLISMO? UMA ANÁLISE DAS MEDIDAS PROTETIVAS DE URGENCLIA NORITODA LEI MARIA DA PENHA
}

MAIQUEL ÂNGELODEZORDI WERMUTH LUIIS GUSTAVO MEZZARI 


\title{
EFICÁCIA OU SIMBOLISMO? UMA ANÁLISE DAS MEDIDAS PROTETIVAS DE URGÊNCIA NO RITO DA LEI MARIA DA PENHA
}

\section{EFFECTIVENESS OR SYMBOLISM? AN ANALYSIS OF PROTECTIVE EMERGENCY MEASURES IN THE RITE OF THE MARIA DA PENHA LAW}

Recebido: 02/03/2021

Aprovado: 21/07/2021
Maiquel Ângelo Dezordi Wermuth ${ }^{1}$ Luís Gustavo Mezzari ${ }^{2}$

\section{RESUMO:}

$\mathrm{O}$ artigo analisa as medidas protetivas de urgência, no enfrentamento à violência doméstica contra a mulher no Brasil, a partir do advento das Leis no $11.340 / 2006$ e no 13.641/2018. A problemática que orienta a pesquisa pode ser sintetizada da seguinte forma: as medidas protetivas de urgência oferecem, efetivamente, proteção e segurança às vítimas de crimes subsumidos ao rito da Lei Maria da Penha durante a fase investigatória e processual e quais outros mecanismos poderiam ser explorados para ampliar a eficácia destas medidas? Parte-se da hipótese de que os mecanismos legais legislados com a finalidade de assegurar a integridade física, psíquica e moral da vítima que recorre à justiça com o intuito de fazer cessar as agressões domésticas, não são capazes de resguardar à mulher seus direitos de proteção descritos na Constituição Federal e na Lei no 11.340/2006, uma vez que são recorrentes os casos de agressão à vítima, por parte do acusado, no decorrer da investigação criminal e do processo judicial. O objetivo geral do estudo consiste em realizar a análise crítica da vigência das medidas protetivas de urgência, para que se possa estabelecer um ponto entre a eficácia prática destas medidas e o seu simbolismo penal. $\mathrm{O}$ método utilizado é o hipotético-dedutivo, com técnica de pesquisa bibliográfica e documental.

Palavras-chave: Violência doméstica contra a mulher. Lei Maria da Penha. Medidas protetivas de urgência.

\begin{abstract}
:
The article analyzes urgent protective measures to tackle domestic violence against women in Brazil, following the advent of Laws $11.340 / 2006$ and 13.641/2018. The problem that guides the research can be summarized as follows: urgent protective measures effectively offer protection and security to victims of crimes under the rite of the Maria da Penha Law during the investigative and procedural phase and what other mechanisms could be explored to increase the effectiveness of these measures? It is based on the hypothesis that the legal mechanisms legislated with the

1 Doutor e Mestre em Direito pela Universidade do Vale do Rio dos Sinos (UNISINOS). Especialista em Direito Penal e Direito Processual Penal e Bacharel em Direito pela Universidade Regional do Noroeste do Estado do Rio Grande do Sul (UNIJUí). Coordenador do Programa de Pós-Graduação Stricto Sensu em Direito - Mestrado e Doutorado em Direitos Humanos - da UNIJUÍ. Professor do Curso de Graduação em Direito da UNIJUÍ. Pesquisador Gaúcho da Fundação de Amparo à Pesquisa do Estado do Rio Grande do Sul (FAPERGS). Líder do Grupo de Pesquisa Biopolítica e Direitos Humanos, certificado pelo Conselho Nacional de Desenvolvimento Científico e Tecnológico (CNPq). Membro da Rede Brasileira de Pesquisa Jurídica em Direitos Humanos. Coordenador do Projeto PROCAD/CAPES "Rede de cooperação acadêmica e pesquisa: eficiência, efetividade e economicidade nas políticas de segurança pública com utilização de serviços de monitoração eletrônica e integração de bancos de dados". Email: madwermuth@gmail.com 2 Advogado. Graduado em Direito pela Universidade do Vale do Rio dos Sinos - UNISINOS. Email: madwermuth@gmail.com
\end{abstract}


purpose of ensuring the physical, psychological and moral integrity of the victim who appeals to justice in order to stop domestic aggressions, are not able to protect women their rights of protection described in the Federal Constitution and Law 11.340/2006, since the cases of aggression to the victim by the accused are recurrent during the course of the criminal investigation and the judicial process. The general objective of the study is to carry out a critical analysis of the duration of emergency protective measures, so that a point can be established between the practical effectiveness of these measures and their criminal symbolism. The method used is the hypothetical-deductive, with bibliographic and documentary research technique.

Keywords: Domestic violence against women. Maria da Penha Law. Urgent protective measures.

\section{CONSIDERAÇÕES INICIAIS}

Por meio do estudo histórico-social da violência doméstica e familiar contra a mulher e de seus (ainda) insuficientes mecanismos legais e sociais de proteção, sobretudo a Lei no 11.340/2006 (Lei Maria da Penha), constata-se que os recursos de tutela e defesa das mulheres no desdobramento do processo judicial, por meio das chamadas "medidas protetivas de urgência", ainda se afiguram como ineficazes no sentido de garantir às vítimas total bem estar e segurança, necessários devido à relação afetuosa e perturbada entre os polos processuais. Isso, por muitas vezes, acaba por gerar danos e/ou riscos maiores à mulher do que aqueles tutelados na própria ação. Desta forma, preocupam-se os legisladores e juristas em dar maior efetividade a estas medidas de proteção imediata, indispensáveis para o pleno desenvolvimento do processo e proteção da mulher, o que se evidencia, no ordenamento jurídico brasileiro, com a promulgação da Lei no 13.641/2018, que visa a ampliar a eficácia destas medidas, tornando crime específico o seu descumprimento.

Neste sentido, o tema da presente pesquisa consiste na análise da eficácia das medidas protetivas de urgência com o advento das Leis n⿳os 11.340/2006 e 13.641/2018 e seus efeitos no enfrentamento à reiteração da violência doméstica e familiar contra a mulher, sob a perspectiva de um sistema penal punitivista que, por muitas vezes, age através do simbolismo para encobrir questões sociais de difícil resolução - a exemplo da violência doméstica.

Assim, a problemática que orienta a presente pesquisa pode ser sintetizada da seguinte forma: as medidas protetivas de urgência oferecem, efetivamente, proteção e segurança às vítimas de crimes subsumidos ao rito da Lei Maria da Penha durante a fase investigatória e processual e quais outros mecanismos poderiam ser explorados para ampliar a eficácia destas medidas?

A análise geral quanto ao tema, que visa a dar uma resposta adequada à presente problemática, partirá da hipótese básica de que os mecanismos legais legislados com a finalidade de assegurar a integridade física, psíquica e moral da vítima que recorre à justiça com o intuito de fazer cessar as agressões domésticas, não são capazes de resguardar à mulher seus direitos de proteção descritos na Constituição Federal e na Lei no 11.340/2006, uma vez que são recorrentes os casos de agressão à vítima, por parte do acusado, no decorrer da investigação criminal e do processo judicial. Isso ocorre muito embora tenha o legislador se preocupado em ofertar à vítima e ao Ministério Público instrumentos legais/processuais que, quando postos em prática, demonstram certo utopismo e, embora não se tenha um estudo específico quanto ao percentual de descumprimento das medidas protetivas no Brasil, a análise comparativa de outras estatísticas aponta para números alarmantes, senão, vejamos: 
a) Conforme dados apresentados pelo Conselho Nacional de Justiça e Departamento de Pesquisas Judiciárias, foram deferidas 236.641 medidas protetivas no ano de 2017 (MONTENEGRO, 2018);

b) Conforme Mapa da Violência 2015: Homicídio de Mulheres no Brasil, a taxa de reincidência de crimes contra a mulher é de quase 50\%, mais especificamente $49,2 \%$ (WAISELFISZ, 2015, p. 51);

c) Em 2016, tramitaram na Justiça do País mais de um milhão de processos referentes à violência doméstica contra a mulher, o que corresponde, em média, a 1 processo para cada 100 mulheres brasileiras, conforme dados divulgados pelo Conselho Nacional de Justiça (BANDEIRA, 2017).

A partir destes dados, é possível observar que o número de medidas protetivas deferidas é pequeno quando comparado com a quantidade de processos em tramitação no país. Para efeito desta pesquisa serão analisadas as informações referentes a 3 (três) anos distintos, uma vez que não se dispõe destas informações em um ano específico. Assim, o período referido serve como uma boa base para esta análise, tendo em vista que os números anuais mudam gradativamente, uma vez que, ao se comparar os números de medidas protetivas deferidas no ano de 2017, com a média de processos referentes à violência doméstica contra a mulher (especificamente neste cálculo, cerca de 1,2 milhões, conforme aponta o site do Conselho Nacional de Justiça (BANDEIRA, 2017) no ano de 2016, obtém-se a média de deferimento de medidas protetivas em $19 \%$ dos processos correntes. Este índice afigura-se como baixíssimo se for levado em consideração o dado de que cerca de $50 \%$ dos casos de violência contra a mulher sofreram com a reincidência no ano de 2015, número este que inexplicavelmente sofreria uma redução significativa nos anos seguintes.

Desta forma, o objetivo geral do presente estudo consiste em demonstrar as imperfeições legislativas e práticas no que tange à proteção da mulher em sede de "pós-denunciação" de violência sofrida no âmbito doméstico, bem como os avanços legais e sociais decorrentes de anos de aprimoramento dos aparatos de defesa e tutela dos interesses das mulheres, sobretudo no que diz respeito à sua segurança. Esta pesquisa também pretende realizar a análise crítica da vigência das medidas protetivas de urgência, utilizando-se dos argumentos e fundamentos da Criminologia em comparação com as diversas fontes estatísticas quanto ao tema e apontamentos doutrinários, para que se possa estabelecer um ponto entre a eficácia prática destas medidas e o seu simbolismo penal.

Os objetivos específicos da pesquisa são: a) realizar um estudo da violência doméstica e familiar contra a mulher com o intuito de verificar os primeiros mecanismos utilizados como forma de medidas protetivas de urgência, bem como sua evolução com o advento da Lei no 11.340/2006 e da Lei no 13.641/2018, que passou a tipificar o crime de descumprimento de medidas protetivas de urgência, ao acrescer o art. 24-A à Lei Maria da Penha; b) especificar as diversas formas de medidas protetivas de urgência que obrigam o agressor e à ofendida, vigentes no ordenamento jurídico brasileiro e dispostas nos artigos 22, 23 e 24 da Lei Maria da Penha; c) analisar métodos ainda não explorados pela legislação que poderiam dar maior efetividade às medidas protetivas de urgência.

A relevância da presente pesquisa se justifica pela extrema importância das medidas protetivas de urgência como forma de garantir às mulheres proteção contra seus agressores, sobretudo, na medida em que o domicílio conjugal, local onde ocorre grande parte das agressões, se torna um verdadeiro campo de exceção à regra (WERMUTH; NIELSSON, 2016).

O debate sobre o tema recebe maior ênfase a partir da publicação da Lei no 13.641/2018 que visa a intimidar os agressores, tipificando o crime de descumprimento de medidas 
protetivas de urgência. Acerca do tema, ainda não se localiza na doutrina uma análise contundente sobre a nova legislação.

Por fim, a presente pesquisa também se justifica pela necessidade de garantir às mulheres sua dignidade e igualdade, que por muitos anos restou prejudicada devido ao arcaico modelo de família patriarcal em que o homem atuava dentro do domicílio sob as próprias regras em uma sociedade que costumeiramente utilizava o bordão "em briga de homem e mulher, não se mete a colher" como forma de vedar os próprios olhos ao problema. Também se justifica em face da impunidade, que por diversas ocasiões resultou na morte da vítima, como forma de resolução do conflito menosprezado pela legislação e pelo Judiciário.

O método utilizado na pesquisa é o hipotético-dedutivo, uma vez que, através da análise doutrinária acerca do tema, bem como de artigos científicos, da jurisprudência de julgados quanto ao assunto e das estatísticas levantadas pelos órgãos competentes, será analisada a proposição inicial, a qual integra o título do presente estudo, como forma de dar uma resposta fundamentada a esta problemática, qual seja, se as medidas protetivas de urgência são, de fato, eficazes ou simbólicas.

\section{UMA ANÁLISE HISTÓRICO-SOCIAL DA VIOLÊNICA CONTRA A MULHER NO ÂMBITO DOMÉSTICO PATRIARCALISTA: A EXCEÇÃO COMO REGRA}

A presente pesquisa tem como marco inicial a análise histórico-social da violência contra a mulher no âmbito doméstico, decorrente do formato de família patriarcal que predominou até, conforme aponta José Aldyr Gonçalves (2009), o final do milênio passado, período este que "já marcava a contestação de suas bases fundamentais, especialmente pelos processos de transformação do trabalho feminino e pela repercussão da conscientização da mulher". No período mencionado, a mulher já havia adquirido certos direitos devido à forte influência do movimento feminista no Brasil, como bem enumera Tatiana Barreira Bastos (2013, p. 19): a) conquista dos direitos políticos, em 1932, formalmente reconhecidos pela Constituição Federal de 1934; b) a igualdade de gêneros, reconhecida em 1948, por meio da Declaração Universal dos Direitos Humanos; e, de um modo mais amplo, c) o reconhecimento da dignidade da pessoa humana no direito interno por meio da Constituição Federal de 1988.

Contudo, muito embora o reconhecimento dos direitos das mulheres estivesse positivado ao final do século, sobretudo, o direito à igualdade, o arcaico formato de família patriarcal continuou a exercer efeitos nas relações domésticas da atualidade. Conforme refere Maria Berenice Dias (2012, p. 19),

durante a maior parte da história, o patriarcado foi incontestavelmente aceito por ambos os sexos e legitimado com base nos papéis de gênero diferenciado, nos valores a eles associados e em uma separação sexual entre as esferas pública e privada.

Porém, embora houvesse uma aceitação deste modelo por ambos os sexos no passado, inegável é que este sexismo, estruturado a partir do patriarcado, teve como resultado uma hierarquia decorrente da diferença biológica de gênero. Este modelo parece ter deixado sequelas permanentes nas relações domésticas e transformado o lar conjugal, entendido como a esfera privada na qual a mulher estava inserida, em um verdadeiro "campo de exceção" (WERMUTH; NIELSSON, 2016).

"A figura da exceção, em determinadas circunstâncias, permite, assim, a suspensão do direito sobre certas pessoas ou grupos, transformando a sua vida em vida nua, ou seja, vida vulnerável, facilmente controlável" (WERMUTH; NIELSSON, 2016, p.15). A partir disto, 
é possível entender a relação doméstica entre o homem e a mulher (esfera privada) como a circunstância determinada e as mulheres como o grupo de direitos suspensos e de vida vulnerável.

Desta forma, o homem passou a exercer dentro deste "campo" a função de soberano, que é aquele quem toma as decisões como detentor do poder dentro do estado de exceção (WERMUTH; NIELSSON, 2016, p.16), restando a mulher como simples cumpridora dos deveres domésticos e maternos. Ocorre que, uma vez submetidas ao poder e às vontades dos patriarcas, as mulheres tiveram suas vidas restringidas à esfera privada, onde eram desprovidas de seus direitos e isoladas do mundo externo. Mais ainda, elas eram afastadas de suas próprias famílias pelo patriarca, como forma de domínio (DIAS, 2012, p. 21), que resultou em uma espécie de lei do silêncio dentro do âmbito doméstico-familiar.

Conforme bem aponta Maria Berenice Dias (2012, p. 20),

acostumada a realizar-se exclusivamente com o sucesso do par e o desenvolvimento dos filhos, a mulher não consegue encontrar, em si, o centro de gratificação própria. O medo, a dependência econômica, o sentimento de inferioridade, de menos valia, decorrentes da ausência de realizações pessoais, impuseram-lhe a lei do silêncio.

O silêncio fez com que por muitos anos a impunidade reinasse na violência de gênero. Isto porque,

em seu íntimo, [a mulher] se acha merecedora da punição por ter deixado de cumprir as tarefas que acredita serem de sua exclusiva responsabilidade. Um profundo sentimento de culpa [que] a impede de usar a queixa como forma de fazer cessar a agressão. (DIAS, 2012, 20).

Como resultado histórico, temos o atual baixo número de queixas prestadas por atos de violência cometidos contra a mulher no espaço doméstico. Há de se destacar, no entanto, que o silêncio não é o problema fim, como aparentar ser, mas sim, o ponto inicial da violência doméstica, na medida em que, conforme aponta Maria Berenice Dias (2012, 21),

primeiro vem o silêncio seguido da indiferença. Depois surgem reclamações, reprimendas, reprovações. Em seguida começam os castigos e as punições. A violência psicológica transforma-se em violência física. Os gritos transformam-se em empurrões, tapas, socos, pontapés, num crescer sem fim.

Desta forma, o silêncio, inserido no lar entendido como um "campo de exceção" controlado pelo "soberano", fez com que a violência doméstica se tornasse um verdadeiro empecilho à vida das mulheres, na medida em que incessantemente introduzia ao seu já conturbado cotidiano uma dose desmesurada de medo e insegurança. Isso constitui um obstáculo a seus direitos já positivados, uma vez que raramente os fatos chegavam às autoridades competentes que pouco faziam e pouco podiam fazer quando tentavam dar uma resolução adequada ao fato. Assim, o lar conjugal passou a ser um dos principais locais em que a violência contra a mulher ocorria e que continua ocorrendo.

Conforme dados levantados por Julio Jacobo Waiselfisz (2015, p. 39), 27,1\% dos homicídios cometidos contra mulheres no ano de 2015 ocorrem em domicílio. Trata-se de um número expressivo se for levado em conta que no caso dos homens a porcentagem do mesmo dado atinge apenas 10,1\%, conforme tabela abaixo: 
Tabela 1 - Homicídios contra homens e mulheres em diferentes espaços

\begin{tabular}{|c|c|c|}
\hline Loeal & Fen & Mase. \\
\hline Estabelecimento saude & 25,2 & 26,1 \\
\hline Domidlio & 27,1 & 10,1 \\
\hline Via poblica & 31,2 & 48,2 \\
\hline Outros & 15,7 & 15,0 \\
\hline Ignorado & 0,8 & 0,7 \\
\hline Total & 100,0 & 100,0 \\
\hline
\end{tabular}

Fonte: Mapa da Violência 2015. Homicídio de mulheres no Brasil.

O "Atlas da Violência 2020 - Principais resultados" aponta que, no ano de 2018, 4.519 mulheres foram assassinadas no Brasil, o que representa uma taxa no patamar de 4,3 homicídios para cada 100 mil mulheres. No país, segundo o relatório, uma mulher é assassinada a cada duas horas. Ainda de acordo com o estudo, "seguindo a tendência de redução da taxa geral de homicídios no país, a taxa de homicídios contra mulheres apresentou uma queda de 9,3\% entre 2017 e 2018." No entanto, observa-se "que a rua foi cenário para $69,4 \%$ dos incidentes, quando a vítima era homem, e 45,1\%, quando mulher". Deste modo, torna-se possível observar "que o percentual de mulheres que sofrem a violência dentro da residência é 2,7 maior do que o de homens, o que reflete a dimensão da violência de gênero e, em particular, do feminicídio." (FÓRUM BRASILEIRO DE SEGURANÇA PÚBLICA, 2020, p. 11).

Como os dados estimam apenas os delitos de homicídios, não levando em conta outros crimes cometidos contra a mulher, bem como por não se referirem apenas a delitos praticados por companheiros ou ex-companheiros, mas sim, por qualquer pessoa, homem ou mulher, o número de homicídios cometidos contra mulheres em via pública é superior aos cometidos em domicílio. Ocorre que, se for levada em conta a ausência destas especificações, pode-se constatar a alta domesticidade dos delitos praticados contra a mulher em comparação aos homens. Sobretudo, se levados em conta os dados do Sistema Único de Saúde que estipulou que, das mulheres atendidas em 2011, 68\% declaram que o agressor se encontrava dentro do lar (BIANCHINI, 2014. p. 78).

Se fosse realizada uma análise superficial, seria possível concluir que o enfraquecimento do modelo familiar patriarcal, resultado da progressiva inserção da mulher na esfera pública, na medida em que "ao se integrar no mercado de trabalho, saiu do lar, impondo ao homem a necessidade de assumir responsabilidades domésticas e de cuidado com a prole" (DIAS, 2012, p. 20), acarretaria a redução, também progressiva, da violência contra a mulher, uma vez que ela estaria se distanciando da vida privada, onde sofria com o silêncio e com a restrição de seus direitos, e se aproximando do mundo externo, onde detentora de direitos já positivados. Contudo, os dados estatísticos divergem desta afirmação lógica, porém precipitada.

Conforme se verifica pela tabela abaixo, desde o ano de 1980 até 2013, houve um aumento de $252 \%$ no número de mulheres vítimas de homicídios, passando de 1.353 vítimas, em 1980, para 4.762, em 2013. É possível verificar, também, que o aumento do número de casos progride anualmente, havendo o aumento de $7,6 \%$ ao ano de 1980 a 2006 , ano que passou a vigorar a Lei Maria da Penha, vindo este número a diminuir de 2006 a 2013, quando passou a aumentar $2,6 \%$ ao ano, o que demonstra o efeito positivo da Lei no combate à violência doméstica (WAISELFISZ, 2015, p. 39). Embora também haja um aumento anual do número de mulheres no país, as taxas para cada 100.000 mulheres, também presentes na tabela, não deixam dúvidas quanto ao progressivo aumento de casos. 
Tabela 2 - Números de mulheres vítimas de homicídios no Brasil (1980-2013)

\begin{tabular}{|c|c|c|}
\hline Ano & n. & Taxas \\
\hline 1980 & 1.353 & 2,3 \\
\hline 1981 & 1.487 & 2,4 \\
\hline 1982 & 1.497 & 2,4 \\
\hline 1983 & 1.700 & 2,7 \\
\hline 1984 & 1.736 & 2,7 \\
\hline 1985 & 1.766 & 2,7 \\
\hline 1986 & 1.799 & 2,7 \\
\hline 1987 & 1.935 & 2,8 \\
\hline 1988 & 2.025 & 2,9 \\
\hline 1989 & 2.344 & 3,3 \\
\hline 1990 & 2.585 & 3,5 \\
\hline 1991 & 2.727 & 3,7 \\
\hline 1992 & 2.399 & 3,2 \\
\hline 1993 & 2.622 & 3,4 \\
\hline 1994 & 2.838 & 3,6 \\
\hline 1995 & 3.325 & 4,2 \\
\hline 1996 & 3.682 & 4,6 \\
\hline 1997 & 3.587 & 4,4 \\
\hline 1998 & 3.503 & 4,3 \\
\hline 1999 & 3.536 & 4,3 \\
\hline 2000 & 3.743 & 4,3 \\
\hline
\end{tabular}

\begin{tabular}{|c|r|c|}
\hline Ano & n. & Taxas \\
\hline 2001 & 3.851 & 4,4 \\
\hline 2002 & 3.867 & 4,4 \\
\hline 2003 & 3.937 & 4,4 \\
\hline 2004 & 3.830 & 4,2 \\
\hline 2005 & 3.884 & 4,2 \\
\hline 2006 & 4.022 & 4,2 \\
\hline 2007 & 3.772 & 3,9 \\
\hline 2008 & 4.023 & 4,2 \\
\hline 2009 & 4.260 & 4,4 \\
\hline 2010 & 4.465 & 4,6 \\
\hline 2011 & 4.512 & 4,6 \\
\hline 2012 & 4.719 & 4,8 \\
\hline 2013 & 4.762 & 4,8 \\
\hline $1980 / 2013$ & 106.093 & \\
\hline$\Delta \% 1980 / 2006$ & 197,3 & 87,7 \\
\hline$\Delta \% 2006 / 2013$ & 18,4 & 12,5 \\
\hline$\Delta \% 1980 / 2013$ & 252,0 & 11,1 \\
\hline$\Delta \%$ aa. $1980 / 2006$ & 7,6 & 2,5 \\
\hline$\Delta \%$ aa. $2006 / 2013$ & 2,6 & 1,7 \\
\hline$\Delta \%$ aa. $1980 / 2013$ & 7,6 & 2,3 \\
\hline & & \\
\hline
\end{tabular}

Fonte: Mapa da Violência 2015. Homicídio de mulheres no Brasil.

Segundo o "Atlas da Violência 2020 - Principais resultados", "entre 2008 e 2018, o Brasil teve um aumento de 4,2\% nos assassinatos de mulheres, sendo que, entre 2013 e 2018 , a taxa de homicídios na residência aumentou 8,3\% havendo estabilidade entre 2017 e 2018 (FÓRUM BRASILEIRO DE SEGURANÇA PÚBLICA, 2020, p. 12).

Desta forma, é possível constatar numericamente que a contestação dos paradigmas da família patriarcal, ocorrida, sobretudo, no "final do milênio passado", conforme referido por José Aldyr Gonçalves (2009), e, logicamente, no início deste século, não é caracterizada pela redução dos casos de violência doméstica e sim pelo seu aumento. Isto porque o patriarcalismo não só atua como fonte de violência contra a mulher, como também a sua gradativa quebra paradigmática acarreta a "ira" do "soberano", fazendo com que este se utilize de todos os empecilhos criados através de anos de patriarcalismo como forma de manter sua dominação sólida, tendo em vista que a horizontalização da relação lhe acarretaria maiores responsabilidades e deveres, bem como a perda de sua imagem social de "homem soberano".

Além de demonstrar a gradatividade anual da violência contra a mulher, a tabela acima é reveladora no sentido de demonstrar que a publicação de leis de proteção à mulher é uma forma eficaz de combater este mal, uma vez que a simples (ou talvez nem tão simples assim, devido ao seu atraso e complexidade) publicação da Lei Maria da Penha (Lei no 11.340/o6) resultou na expressiva redução das taxas de casos de homicídio contra a mulher no ano seguinte à sua vigência, qual seja, o ano de 2007 . Infelizmente, já no ano de 2008 a taxa voltou a se igualar ao ano da publicação da Lei e continuou a aumentar, devido à ineficácia de alguns dispositivos nela presentes, mormente, as medidas protetivas de urgência. É sobre essas medidas que se ocupa o tópico seguinte.

\section{AS MEDIDAS PROTETIVAS DE URGÊNCIA NA LEI MARIA DA PENHA E O ADVENTO DA LEI № 13.641/2018}

Embora a Lei Maria da Penha tenha constituído "avanço inovador do Brasil em sede de direitos humanos, mostrando-nos, em agosto de 2006, como o 18º país da América Latina a aperfeiçoar sua legislação sobre a proteção da mulher" (JESUS, 2015, p. 52), esta legislação e seus institutos ainda são objeto de muitas críticas. No entanto, por serem objeto do presente 
estudo as medidas protetivas de urgência, serão enfocadas as análises e críticas ao que diz respeito às referidas medidas.

Para Alice Bianchini (2014, p. 178),

as medidas protetivas de urgência constituem a principal inovação da Lei Maria da Penha ao lado da criação dos Juizados de Violência Doméstica e Familiar contra a Mulher. Até então, o juiz, nesses casos, encontrava-se muito limitado nas suas ações voltadas à proteção da mulher [...] As medidas protetivas permitiram não só alargar o espectro de proteção da mulher, aumentando o sistema de prevenção e combate à violência, como também dar ao magistrado uma margem de atuação para que possa decidir por uma ou outra medida protetiva, de acordo com a necessidade exigida pela situação.

Consoante se depreende da lição de Alice Bianchini, o juiz, antes da criação do instituto das medidas protetivas, possuía uma limitação muito forte em sua atuação na proteção da mulher. Assim, para melhor compreensão da importância dada pelos doutrinadores ao referido instituto, é necessário, antes de realizar uma análise mais profunda de suas características, compreender e examinar o panorama legal anterior ao advento da Lei Maria da Penha.

Inicialmente, deve-se levar em consideração o fato de que a legitimidade para julgar os casos de violência doméstica pertencia aos Juizados Especiais Criminais, tendo em vista que a promulgação da Lei no 10.886/2004, que inseriu o $§ 9^{0}$ ao art. 129, do Código Penal (lesões corporais), aumentou em 3 (três) meses a pena mínima do delito em sua forma simples, não havendo modificações em sua pena máxima, passando a viger da seguinte forma:

Art. 129. Ofender a integridade corporal ou a saúde de outrem:

Pena - detenção, de três meses a um ano.

[...]

$\S 9^{\text {o }}$ Se a lesão for praticada contra ascendente, descendente, irmão, cônjuge ou companheiro, ou com quem conviva ou tenha convivido, ou, ainda, prevalecendo-se o agente das relações domésticas, de coabitação ou de hospitalidade.

Pena - detenção, de 6 (seis) meses a 1 (um) ano. (BRASIL, 1940)

Por não possuir pena máxima superior a 1 (um) ano, tendo em vista que o art. 61, da Lei no 9.099/1995, ainda não havia sido alterado por força da Lei no 11.313/2006, que agora prevê que a pena máxima não pode ser superior a 2 (dois) anos para que se considere infração penal de menor potencial ofensivo, aplicava-se o rito dos Juizados Especiais Criminais.

Conforme aponta Damásio de Jesus (2015, p. 51),

com a agravação da pena mínima de detenção, de 3 para 6 meses, não ficara afastada a aplicação da transação penal (art. 76, da Lei no 9.099/95) nem do sursis processual (art. 89 da mesma lei), sendo cabíveis as penas restritivas de direitos (art. 44 do CP). Quanto à ação penal, tratando-se de lesão corporal leve (\$9º), a iniciativa da autoridade policial e do Ministério Publico dependia da representação da ofendida (art. 88 da Lei dos Juizados Especiais Criminais).

Desta forma, os acusados por lesões corporais contra a mulher eram facilmente liberados a retornarem ao domicílio comum em virtude da possibilidade de transação penal e sursis processual, não havendo qualquer possibilidade de decretação de medidas de proteção à mulher e, sequer, prisão preventiva. Ainda, o juiz não podia agir de ofício, tampouco a autoridade policial e o Ministério Público podiam dar continuidade ao procedimento acusatório sem a anuência da vítima, salvo nos casos de "lesão corporal grave, gravíssima ou seguida da morte (art. 129, $\S \S 1^{\circ}, 2^{\circ}$ e $3^{\circ}$ ), praticada em qualquer das circunstâncias definidoras da violência doméstica 
contra a mulher (§9ำ” (JESUS, 2015, p. 51), sendo que a ação penal já possuía a forma pública e incondicionada à representação.

Tal panorama de impunidade e de desconsideração com a proteção da mulher restou por demonstrar significativo avanço apenas dois anos após a promulgação da Lei no 10.886/2004, com a entrada em vigor da Lei no $11.340 / 2006$, que acarretou inúmeros benefícios à efetiva defesa da mulher em face da violência doméstica, por meio: a) da criação das medidas protetivas de urgência que obrigam o agressor e à ofendida (art. 18 a 24); b) do descabimento da suspensão condicional do processo aos crimes praticados contra a mulher no contexto de violência doméstica (art. 41); c) do aumento da pena máxima de detenção do §9º , do art. 129, do Código Penal, de 1 (um) ano para 3 (três) anos (art. 44), afastando-se, assim, a competência dos Juizados Especiais Criminais e a possibilidade de transação penal ou acordo civil extintivo de punibilidade; d) da admissão de prisão preventiva em crimes que envolvem violência doméstica e familiar contra a mulher, como forma de garantir a execução das medidas protetivas de urgência, com a inserção do inc. IV, ao art. 313, do Código de Processo Penal (art. 42); e) da inclusão da violência contra a mulher no rol de agravantes genéricas de pena do art. 61, do Código Penal (art. 43), e; f) da criação de medidas integradas de prevenção, de assistência e de atendimento pela autoridade policial à mulher (título III).

No que diz respeito à decretação da prisão preventiva, importante destacar que

apesar de o Código de Processo Penal não mais admitir a decretação da prisão preventiva de ofício pelo juiz, na fase do inquérito policial, em sede de violência doméstica esta restrição não vinga, pois expressamente tal possibilidade é prevista na Lei Maria da Penha (art. 20). Por ser lei especial, prevalece sobre a regra geral. (DIAS, 2012, p. 8o)

Ante tais inclusões e alterações legislativas, o combate à violência doméstica contra a mulher recebeu instrumentos capazes de suprirem certas lacunas normativas, no que diz respeito à proteção da vítima, e de darem maior efetividade àquelas já existentes, possibilitando, também, que o juiz e o Ministério Público utilizassem tais instrumentos de forma menos restrita, promovendo uma atuação mais eficaz do Estado.

Como resultado, no ano de $\mathbf{2 0 0 7}$, ou seja, um ano após a publicação desta Lei, houve significativa redução no número de casos de homicídios praticados contra mulheres, bem como uma redução no percentual de aumento anual dos casos, conforme se verifica pela Tabela 2, supra, o que demonstra que tais inclusões e alterações provocadas pela Lei Maria da Penha surtiram tanto efeitos sociais como jurídicos, capazes de inibir a ocorrência de algumas novas agressões, em seus diversos modos, de afastar a reincidência e de solucionar o problema quanto à impunidade dos agressores.

A criação das medidas protetivas de urgência teve especial relevância no que diz respeito ao enfrentamento direto à reincidência e à impunidade pré-julgamento, bem como ao enfrentamento indireto de ocorrência de novos delitos. Neste sentido, Tatiana Barreira Bastos (2013, p. 138), aponta que

as medidas protetivas de urgência, de cunho preventivo e protetivo e de caráter penal, extrapenal e administrativo, são mecanismos fundamentais às mulheres que estejam em situação de risco, possibilitando-lhes uma providência jurisdicional imediata antes mesmo do início do processo judicial.

Conforme já destacado, as medidas protetivas de urgência se dividem em: a) medidas protetivas de urgência que obrigam o agressor; e b) medidas protetivas de urgência à vítima. 
A primeira modalidade se encontra disposta no art. 22, da Lei Maria da Penha3. Conforme se pode verificar, esta modalidade de medidas protetivas de urgência impõe uma ação negativa ao agressor, ou seja, uma abstenção a praticar determinados atos, como se aproximar ou manter contato com a vítima e frequentar determinados lugares, bem como suspende e restringe determinados direitos, como a posse e o porte de arma de fogo. Ainda, percebe-se que tais determinações não se limitam à pessoa da vítima, podendo o agressor ser afastado ou obrigado a deixar de manter contato com os familiares da vítima e com as testemunhas, como forma de garantir a instrução criminal e, até mesmo, ter restringido ou suspenso o direito de visitar os dependentes menores.

Há de se destacar que, "por terem a natureza jurídica de medidas cautelares, devem observar, para a sua decretação, a presença de fumus commissi delicti e do periculum libertatis" (BASTOS, 2013, p. 143), e só poderão "ser solicitadas pelas vítimas ou pelo Ministério Público em fatos revestidos de tipicidade e justa causa, pois possuem o objetivo de antecipar a tutela penal à vítima em situação de risco" (BASTOS, 2013, p. 144).

Por outro lado, as medidas protetivas de urgência à ofendida, estão dispostas nos arts. $23^{4}$ e $24^{5}$, da Lei Maria da Penha. Pode-se constatar que o art. 23 possui caráter de proteção à pessoa da vítima, enquanto o art. 24 possui caráter de proteção aos bens desta ou ao patrimônio do casal. Sobre o tema, Alice Bianchini (2014, p. 185-186) salienta que,

dentre as medidas protetivas dirigidas à mulher, nenhuma delas possui natureza criminal, podendo ser cumuladas, ou não, com as outras, a depender da complexidade e das peculiaridades do caso concreto"

Para ter conhecimento, foram concedidas 236.641 medidas protetivas no ano de 2017 , sendo que 38.664 foram concedidas por magistrados da Justiça gaúcha, conforme apontam dados do Conselho Nacional de Justiça (MONTENEGRO, 2018).

3 Art. 22. Constatada a prática de violência doméstica e familiar contra a mulher, nos termos desta Lei, o juiz poderá aplicar, de imediato, ao agressor, em conjunto ou separadamente, as seguintes medidas protetivas de urgência, entre outras:

I - suspensão da posse ou restrição do porte de armas, com comunicação ao órgão competente, nos termos da Lei no 10.826, de 22 de dezembro de 2003;

II - afastamento do lar, domicílio ou local de convivência com a ofendida;

III - proibição de determinadas condutas, entre as quais:

a) aproximação da ofendida, de seus familiares e das testemunhas, fixando o limite mínimo de distância entre estes e o agressor;

b) contato com a ofendida, seus familiares e testemunhas por qualquer meio de comunicação;

c) frequentação de determinados lugares a fim de preservar a integridade física e psicológica da ofendida;

IV - restrição ou suspensão de visitas aos dependentes menores, ouvida a equipe de atendimento multidisciplinar ou serviço similar; $\mathrm{V}$ - prestação de alimentos provisionais ou provisórios.

$\S$ 1ํ- As medidas referidas neste artigo não impedem a aplicação de outras previstas na legislação em vigor, sempre que a segurança da ofendida ou as circunstâncias o exigirem, devendo a providência ser comunicada ao Ministério Público.

$\S$ 2ํNa hipótese de aplicação do inciso I, encontrando-se o agressor nas condições mencionadas no caput e incisos do art. 6o da Lei no 10.826, de 22 de dezembro de 2003, o juiz comunicará ao respectivo órgão, corporação ou instituição as medidas protetivas de urgência concedidas e determinará a restrição do porte de armas, ficando o superior imediato do agressor responsável pelo cumprimento da determinação judicial, sob pena de incorrer nos crimes de prevaricação ou de desobediência, conforme o caso.

$\S 3^{\circ}$ Para garantir a efetividade das medidas protetivas de urgência, poderá o juiz requisitar, a qualquer momento, auxílio da força policial. $\S 4^{\circ}$ Aplica-se às hipóteses previstas neste artigo, no que couber, o disposto no caput e nos $\S \S 50$ e 6 o do art. 461 da Lei no 5.869, de 11 de janeiro de 1973 (Código de Processo Civil). (BRASIL, 2006).

4 Art. 23. Poderá o juiz, quando necessário, sem prejuízo de outras medidas:

I - encaminhar a ofendida e seus dependentes a programa oficial ou comunitário de proteção ou de atendimento;

II - determinar a recondução da ofendida e a de seus dependentes ao respectivo domicílio, após afastamento do agressor;

III - determinar o afastamento da ofendida do lar, sem prejuízo dos direitos relativos a bens, guarda dos filhos e alimentos;

IV - determinar a separação de corpos (BRASIL 2006).

5 Art. 24. Para a proteção patrimonial dos bens da sociedade conjugal ou daqueles de propriedade particular da mulher, o juiz poderá determinar, liminarmente, as seguintes medidas, entre outras:

I - restituição de bens indevidamente subtraídos pelo agressor à ofendida;

II - proibição temporária para a celebração de atos e contratos de compra, venda e locação de propriedade em comum, salvo expressa autorização judicial;

III - suspensão das procurações conferidas pela ofendida ao agressor;

IV - prestação de caução provisória, mediante depósito judicial, por perdas e danos materiais decorrentes da prática de violência doméstica e familiar contra a ofendida.

Parágrafo único. Deverá o juiz oficiar ao cartório competente para os fins previstos nos incisos II e III deste artigo. (BRASIL, 2006). 
Contudo, devem ser levantadas certas fragilidades práticas quanto às medidas protetivas de urgência. Isso porque inúmeros são os casos de novas agressões contra vítimas que possuem tais medidas em seu favor, o que se dá em virtude da ineficácia, e até mesmo impossibilidade, de os órgãos de segurança garantirem sua vigência durante 24 horas por dia. Conforme aponta Sandra Fernandes Biagi (2014, p. 27), "o descumprimento da medida protetiva somente é verificado se a vítima comparecer a delegacia e comunicar o fato. Normalmente o descumprimento vem acompanhado de outro crime e não somente da desobediência judicial.".

Desta forma, verifica-se que a ausência de fiscalização do instrumento o torna, por vezes, ineficiente, dando margem à ocorrência de novas agressões contra a mulher, senão, o cometimento de feminicídio, fomentado pela ira do agressor já denunciado que possui como empecilho à concretização de sua cogitação apenas um documento em suas mãos ordenandolhe a não se aproximar da vítima.

Por outro lado, o descumprimento das medidas protetivas gerou discussão jurisprudencial quanto à sua caracterização como crime de desobediência, previsto no art. 330, do Código Penal. Isto porque, embora os Tribunais Estaduais estivessem reconhecendo a atipicidade da conduta, mesmo antes do posicionamento do Superior Tribunal de Justiça, inúmeras eram as denúncias recebidas pelo Judiciário nestes termos, conforme se pode averiguar, exemplificativamente, dos seguintes julgados:

a) Tribunal de Justiça do Rio Grande do Sul:

APELAÇÃO CRIME. DESOBEDIÊNCIA (ART. 330 CP). MEDIDA PROTETIVA DEFERIDA COM BASE NA LEI MARIA DA PENHA. ATIPICIDADE DA CONDUTA. MANTIDA DECISÃO QUE REJEITOU A DENÚNCIA. Atipicidade da conduta que se reconhece na medida em que a Lei no 11.340/o6 prevêa possibilidade de decretação da prisão preventiva na hipótese de descumprimento da medida protetiva. Ausência de previsão legal para a cumulativa aplicação do art. 330 do CP. APELO IMPROVIDO. (Recurso Crime № 71003939295, Turma Recursal Criminal, Turmas Recursais, Relator: Eduardo Ernesto Lucas Almada, Julgado em 17/12/2012).

b) Tribunal de Justiça do Rio de Janeiro:

APELO DEFENSIVO - VIOLÊNCIA DOMÉSTICA E FAMILIAR - PROVA CERTA DA AUTORIA E FATOS PENAIS, OCORRÊNCIA AOS 12/o9/10 - ALTERAÇÃO DO ARTIGO 109, VI DO CP, QUANTO À PRESCRIÇÃO, LEI 12.234/10, AOS o5 DE MAIO DE 2010 LESÃO CORPORAL - CONDUTA ENDEREÇADA À EX-COMPANHEIRA, INCIDINDO, NA HIPÓTESE, O PAR. 9 ํD DORT. 129 DO CP - SEGUNDO FATO, LESÃO CORPORAL SIMPLES, ATUAR VOLTADO AO ATUAL CONVIVENTE DA EX-MULHER - AMEAÇA, ART. 147 DO CP, DUAS VEZES, PRATICADA CONTRA A EX-COMPANHEIRA E SEU PARCEIRO - DESOBEDIÊNCIA À ORDEM LEGAL, ESTA CONSISTENTE EM MEDIDA PROTETIVA QUE FOI IMPOSTA EM FAVOR DA EX-MULHER - MOSTRA DA INTIMAÇÃO E DESRESPEITO AO COMANDO AO APROXIMAR-SE E EMPURRÁLA. PORÉM, PREVISÃO DE SANÇÃO ESPECÍFICA, INCLUSIVE COM A PRISÃO PREVENTIVA - AFASTAMENTO - DELITOS PERTINENTES À LEI MARIA DA PENHA, EM CONTINUIDADE - ABSOLVIÇÃO PELO ARTIGO 330 DO CP. DOSIMETRIA - PELO

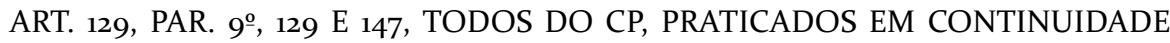
DELITIVA, ADOTADA COMO BASE DE CÁLCULO A DO CRIME MAIS GRAVE (ART. 129, PAR. 9º, DO CP), EM oı (HUM) ANO DE DETENÇÃO QUE FOI ELEVADA EM 1/6 (UM SEXTO), PELA CONTINUIDADE EM RELAÇÃO AO DE LESÃO CORPORAL LEVE E OS DE AMEAÇA (DUAS VEZES) - NEGADA A SUBSTITUIÇÃO E O SURSIS - REGIME SEMIABERTO - REPRIMENDAS QUE SE MANTÉM - MOTIVAÇÃO SUFICIENTE E CONSIDERAÇÃO LANÇADA POR ANTECEDENTE CONDENAÇÃO, INOBSTANTE SEM TRÂNSITO EM JULGADO - FRAÇÃO MÍNIMA, PELA CONTINUIDADE (EM ⿳o GRAU), 1/6 (UM SEXTO) - 1(HUM) ANO E 2(DOIS) MESES DE DETENÇÃO. PENA 
ALTERNATIVA EM o1(UMA) RESTRITIVA DE DIREITO REPRESENTANDO A MELHOR RESPOSTA PENAL - REGIME PRISIONAL QUE SE ALTERA PARA O ABERTO. POR UNANIMIDADE E NOS TERMOS DO VOTO DA RELATORA FOI DADO PARCIAL PROVIMENTO AO APELO PARA ABSOLVER O RECORRENTE DO CRIME DO ART. 330 DO CÓDIGO PENAL, FIXANDO-SE O REGIME INICIAL ABERTO, SUBSTITUINDO-SE, AINDA, A PRIVATIVA DE LIBERDADE POR UMA RESTRITIVA DE DIREITOS. (Des(a). ROSITA MARIA DE OLIVEIRA NETTO - Julgamento: 11/12/2012 - SEXTA CÂMARA CRIMINAL - o000165-27.2011.8.19.0044 - APELAÇÃO).

c) Tribunal de Justiça do Paraná:

APELAÇÃO CRIMINAL CRIME DE DESOBEDIÊNCIA ART. 330 DO CÓDIGO PENAL DESCUMPRIMENTO DE MEDIDA PROTETIVA DE AFASTAMENTO LIMINAR PREVISTA NO ART. 22 DA LEI 11.340/2006 (LEI MARIA DA PENHA) AUSÊNCIA DE PREVISÃO DE PENALIDADE ESPECÍFICA PARA DESCUMPRIMENTO DA REFERIDA ORDEM - ELEMENTOS DE AUTORIA E MATERIALIDADE OBSERVADOS NO CASO CONCRETO CRIME FORMAL - SENTENÇA MANTIDA. ı. DECISÃO : Ante o exposto, a $\mathbf{1}^{\mathbf{a}}$ Turma RecursaldoEstadodo Paranáresolve, porunanimidadedevotos, CONHECERENEGAR PROVIMENTO ao recurso, nos exatos termos do voto. (Relator: Mychelle Pacheco Cintra/ Processo:20110013666-/Acórdão:4988/Fonte:805/DataPublicação:27/04/20 12/ ÓrgãoJulgador:1ª̂TurmaRecursal/DataJulgamento:19/04/2012).

Em sede de julgamento do Recurso Especial 1.387.885-MG, o Superior Tribunal de Justiça firmou o seguinte entendimento:

\begin{abstract}
A questão trazida no presente recurso limita-se a determinar se constitui o crime de desobediência o descumprimento injustificado de medida protetiva imposta judicialmente nos termos da lei 11.340/o6”. Quanto ao tema, a posição doutrinária mais correta é aquela que afasta a tipicidade da conduta nos casos em que o descumprimento da ordem é punido com sanção específica de natureza civil ou administrativa. Neste sentido é a lição de André Estefam (Direito Penal, vol. 4, São Paulo: Saraiva, 2011): Casos há em que a lei comina sanções específicas (civis ou 3 administrativas) ao ato do particular que desrespeita o comando emanado por funcionário público. Quando isso ocorrer, a caracterização do crime de desobediência ficará condicionada à existência de previsão expressa nesse sentido no preceito violado. É o que se dá, por exemplo, quando a testemunha desatende ao chamado judicial, pois o art. 458 do CPP dispõe que ela ficará sujeita ao pagamento de multa (sanção administrativa), sem prejuízo da ação penal pela desobediência. Se esta ressalva não existir, o inadimplemento do comando emitido não configurará o delito em questão. Assim, por exemplo, se um motorista deixa de cumprir a ordem de um guarda de trânsito, no sentido de retirar um veículo de determinado local, não pratica delito contra a Administração Pública, justamente porque a lei de trânsito prescreve sanções na órbita administrativa (como multa de trânsito e o guinchamento do veículo, nada dispondo sobre o crime de desobediência).
\end{abstract}

A partir desta decisão do Superior Tribunal de Justiça concretizou-se a existência de uma lacuna normativa quanto à tipificação do delito de descumprimento de medidas protetivas de urgência, resultando na impunidade de todos aqueles que desobedeciam à ordem legal, motivo pelo qual, em 2015, originou-se na Câmara dos Deputados o PL 173/15, transformado na Lei Ordinária no 13.641/2018, publicada em o3 de abril de 2018, que incluiu na Lei no 11.340/o6 o art. 24-A, com a seguinte redação:

Art. 24-A. Descumprir decisão judicial que defere medidas protetivas de urgência previstas nesta Lei:

Pena - detenção, de 3 (três) meses a 2 (dois) anos. 
§ 1o A configuração do crime independe da competência civil ou criminal do juiz que deferiu as medidas.

$\S 2^{\mathbf{o}}$ Na hipótese de prisão em flagrante, apenas a autoridade judicial poderá conceder fiança.

$\S 3^{\circ}$ O disposto neste artigo não exclui a aplicação de outras sanções cabíveis. (BRASIL, 2018)

Por ser uma novatio legis, pouco ainda se lê a respeito dela. Contudo, algumas considerações hão de serem traçadas. Por primeiro, notório é que o referido diploma legal, com a inserção do artigo supradescrito, supriu a lacuna normativa quanto à ausência de tipificação do delito, já estando presente nas jurisprudências de nossos Tribunais de Justiça Estaduais. Apenas para título de demonstração, segue abaixo ementa oriunda de julgado do Tribunal de Justiça do Rio Grande do Sul:

APELAÇÃO CRIMINAL. VIOLÊNCIA DOMÉSTICA. AMEAÇA. DESCUMPRIMENTO DE MEDIDA PROTETIVA. ART. 24-A, DA LEI № 11.346/o6. PROVA SUFICIENTE. PALAVRA DA VÍTIMA E TESTEMUNHA PRESENCIAL. RÉU PRESO EM FLAGRANTE AO DESCUMPRIR MEDIDA PROTETIVA EM VIGOR. SENTENÇA CONDENATÓRIA MANTIDA. PENA REDIMENSIONADA. CONCEDIDO SURSIS ESPECIAL E HABEAS CORPUS DE OFÍCIO. Nos casos de violência doméstica a palavra da vítima merece especial relevância, em face da forma como os delitos são habitualmente perpetrados, sem a presença de testemunhas, porém não é absoluta, deve guardar coerência com os demais elementos probatórios colhidos ao longo da persecução penal. No caso concreto o réu dirigiu-se até a residência da vítima, ameaçando-a de morte, estando em vigor medidas protetivas a proibir sua aproximação da ofendida. Prova suficiente a ensejar a condenação, sendo a palavra da vítima firme, coerente e reiterada em todas as fases da persecução penal, corroborada pelo relato da testemunha presencial, sobrinho da vítima. Temor da vítima demonstrado. Réu que descumpre determinação judicial consistente em medidas de proteção à vítima de violência doméstica, incide no descumprimento à previsão do artigo 24-A, da Lei no 11.340/o6. Condenação mantida. Pena redimensionada em razão de afastamento de circunstância agravante, fazendo jus o réu ao benefício do sursis especial nos termos do $\S 2^{\circ}$, do artigo 78, do Código Penal. Réu preso desde a data do flagrante. Habeas corpus concedido, de ofício. RECURSO IMPROVIDO. (Apelação Crime № 70077928554, Terceira Câmara Criminal, Tribunal de Justiça do RS, Relator: Ingo Wolfgang Sarlet, Julgado em 15/o8/2018).

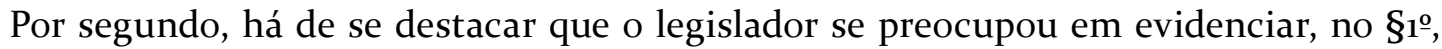
do artigo em questão, que para a configuração do crime, independe se a competência do juiz é civil ou criminal, a fim de afastar possíveis discussões prolongadas que poderiam causar prejuízos à vítima enquanto não fosse pacificado certo entendimento. Neste mesmo sentido, explicitou no $\mathbf{2}^{\circ}{ }^{\circ}$ que apenas o juiz poderá conceder fiança ao acusado, como forma também de conferir maior proteção à vítima, na medida em que o juiz deverá analisar todos os fatos e provas presentes no inquérito policial antes de ofertá-la.

Ainda, quanto ao $\S 3^{\circ}$ do artigo em questão, cabe salientar que o juiz poderá aplicar não só outras medidas protetivas de urgência como também decretar a prisão preventiva do acusado, que até então estava sendo entendida como ilegal em virtude da ausência de delito tipificado.

Por fim, como o referido artigo foi incluído na Lei Maria da Penha, há de se ressaltar que os benefícios da Lei 9.099/95 não são aplicáveis. Neste sentido, é a Súmula 536, do Superior Tribunal de Justiça, que dispõe que "a suspensão condicional do processo e a transação penal não se aplicam na hipótese de delitos sujeitos ao rito da Lei Maria da Penha”.

Desta forma, mais uma questão que por muito gerou divergência nos diversos tribunais estaduais, acarretando inaplicação de sanção a fatos visivelmente contrários à legislação e danosos a diversos bens jurídicos tutelados pela Lei no 11.340/2006, tais quais a integridade 
física, psicológica, sexual, econômica e moral da mulher, conforme se extrai do art. $5^{\mathbf{o}}$, da própria Lei Maria da Penha, restou solucionada em razão da promulgação de lei objetiva (Lei no 13.641/2018), demonstrando, por conseguinte, que determinadas contradições, omissões e lacunas presentes na Lei Maria da Penha dependem da promulgação de novas leis que as façam cessar, tendo em vista que, embora também fontes do direito, a jurisprudência e a doutrina, em sua pluralidade, nem sempre são capazes de consolidar quaisquer entendimentos, gerando margem à interpretação do aplicador da Lei.

A criação de "leis de apoio", promulgadas com o objetivo de constituir entendimento a institutos legais em nosso sistema jurídico é, evidentemente, a forma mais eficiente para que se possa alcançar maior eficácia de cada diploma legal, motivo pelo qual o legislador deve atentar aos debates doutrinários e jurisprudenciais gerados por leis complexas como a Maria da Penha, para que possa, no plano positivo, solucionar os vícios existentes.

A propósito do tema, cumpre salientar que, recentemente, o Conselho Nacional de Justiça $(\mathrm{CNJ})$ editou duas importantes Resoluções com vistas a complementar o arcabouço jurídico-normativo de mecanismos para coibir a violência doméstica contra a mulher no Brasil. Tratam-se das Resoluções de n⿳o 342, de 9 de setembro de 2020, e ํㅜ 346, de 8 de outubro de 2020.

A Resolução CNJ no 342, de 9 de setembro de $2020^{6}$, institui e regulamenta o Banco Nacional de Medidas Protetivas de Urgência (BNMPU), o qual tem por finalidades: a) identificar, de forma individualizada, as medidas protetivas de urgência; b) verificar, em diferentes unidades da Federação, se as medidas protetivas foram concedidas, concedidas parcialmente, revogadas ou homologadas; c) possibilitar a fiscalização, o monitoramento e a efetividade da medida protetiva pelo Ministério Público, pela Defensoria Pública, pelos órgãos de segurança pública e por assistentes sociais; e d) permitir ao Poder Judiciário a produção de estatísticas sobre as medidas protetivas de urgência.

Por sua vez, a Resolução CNJ no 346 , de 8 de outubro de $2020^{7}$, no intuito de assegurar a efetividade do comando judicial que imponha medida protetiva de urgência no resguardo da integridade física e psíquica da vítima de violência doméstica e familiar contra a mulher, dispõe sobre o prazo para cumprimento, por oficiais de justiça, de mandados referentes às medidas protetivas de urgência, bem como sobre a forma de comunicação à vítima dos atos processuais relativos ao agressor, especialmente dos pertinentes ao seu ingresso e à saída da prisão. Dentre as medidas que merecem destaque estão: a) a necessidade de cumprimento dos mandados referentes às medidas no prazo máximo de 48 horas, a contar da respectiva carga ao oficial de justiça (art. $1^{\circ}$ ); b) a comunicação imediata da decisão que deferir ou indeferir pedido de prisão cautelar ou de imposição de medida protetiva de urgência, bem como do ingresso e saída do agressor da prisão (art. 2º̄); c) a possibilidade de a vítima receber notificação por telefone fixo, celular, WhatsApp ou e-mail, sem prejuízo de sua eventual e posterior intimação por mandado (art. $3^{\circ}$ ).

Restam, portanto, evidenciadas as importantes alterações procedimentais voltadas ao combate à violência de gênero em virtude da entrada em vigor da Lei no 11.340/2006, bem como a importância dada às medidas protetivas de urgência no que concerne a proteção da vítima desta violência, demonstrando, entretanto, que existem certas omissões em seu rito, que buscavam na jurisprudência solução adequada. Ainda, alguns institutos podem apresentar punição exacerbada se não analisados sob a óptica da necessidade e da proporcionalidade ao caso, o que faz com que a referida Lei seja interpretada por muitas vezes como integrante do processo de expansão do direito penal e, consequentemente do simbolismo de normas, tendo em vista que, embora a Lei Maria da Penha tenha acarretado diversos benefícios no combate à

6 Texto integral disponível em: <https://atos.cnj.jus.br/atos/detalhar/3564>. Acesso em: 11 jan. 2021. 7 Texto integral disponível em: <https://atos.cnj.jus.br/atos/detalhar/3513>. Acesso em: 11 jan. 2021. 
violência doméstica, os números estatísticos não são positivos no que diz respeito à erradicação da violência contra a mulher, como evidenciam as estatísticas já apresentadas.

Desta forma, o próximo tópico apresenta novos dados relativos à violência de gênero para que se possa, ao final, encontrar o lócus dos maiores problemas ainda não solucionados pelo novo procedimento, para que, ao final, seja possível realizar a análise cerne do presente trabalho, consubstanciada na análise quanto à eficácia ou simbolismo penal da Lei Maria da Penha e demais legislações que buscam dar maior efetividade aos seus objetivos.

\section{ENTRE EFICÁCIA E SIMBOLISMO: A LEI MARIA DA PENHA E SUAS ALTERAÇÕES}

Em tempos de expansão do direito penal é de extrema importância que as normas punitivistas e restritivas de determinados direitos já existentes em nosso ordenamento jurídico sejam avaliadas quanto à sua validade frente à legislação, sua plena eficácia e quanto à adequada imposição de sanções como método de resolução de conflitos e de situações socialmente inadmitidas.

Ora, se não houver tal controle, tais normas irão coabitar em um sistema enraizado de preceitos penalizadores que de tempo em tempo dissemina novas leis criadoras de sanções das mais variadas espécies em nosso ordenamento jurídico, resultado de uma onda punitivista que não para de crescer em países como o Brasil.

Desta forma, não apenas as leis a serem promulgadas ou recentemente vigentes devem ser objeto de análise pela ótica da criminologia, mas também as normas já implementadas e consolidadas em nossa legislação, para que o enfrentamento à expansão desenfreada do direito penal possa erradicar injustiças e desrespeitos à dignidade humana já solidificados em nosso país, que apresenta, diga-se de passagem, a terceira maior população carcerária do mundo. Com 748.009 custodiados $^{8}$, nos termos do Levantamento Nacional de Informações Penitenciárias - Período de Julho a Dezembro de 2019 (BRASIL, 2019), o Brasil ocupa a terceira colocação no ranking mundial de segregados e demonstra como o controle social vem sendo utilizado no país como ferramenta essencial no pretenso combate à criminalidade com a reivindicação e/ou anuência do tecido societal em relação ao recrudescimento das normas criminais e, inclusive, à relativização/supressão de direitos humanos.

Torna-se, então, de extrema valia a demonstração de efetividade na aplicação das medidas protetivas de urgência previstas na Lei Maria da Penha, bem como dos demais mecanismos presentes no diploma legal, como forma de se apurar se é possível afastá-las da onda do punitivismo e reconhecê-las como capazes de combater funcionalmente a problemática a qual se destinam, na medida em que a existência de normas criadas com o intuito único de aplacar o clamor social, mas que não apresentam eficácia plena, denominadas pelos criminólogos como sendo de caráter simbólico, "representa a alternativa mais 'barata' na hora de articular soluções para problemas sociais, visto que as medidas e programas sociais sempre são mais custosos do ponto de vista financeiro" (CALLEGARI, WERMUTH, 2010, p. 56), motivo pelo qual são escolhidas pelo Estado como primacial resposta aos problemas sociais.

Há de ser verificar, portanto, se as normas em análise realmente são capazes de apresentar vantagens ao fim a que se destinam, como forma de melhor conceituar a dicotomia apresentada.

8 O aumento da população carcerária é gradativo no Brasil. Em 1990, havia 90 mil presos; em 1992, 114,3 mil; em 1993, 126,2 mil; em 1994, 129,2 mil; em 1995, 148,8 mil; em 1997, 170,6 mil; em 1999, 194,1 mil; em 200o, 232,8 mil; em 2001, 233,9 mil; em 2002, 239,3 mil; em 2003, 308,3 mil; em 2004, 336,4 mil; em 2005, 361,4 mil; em 2006, 401,2 mil; em 2007, 422,4 mil; em 2008, 451,4 mil; em 2009, 473,6 mil; em 2010, 493,3 mil; em 2011, 514,6 mil; em 2012, 549,8 mil; em 2013, 581,5 mil; em 2014, 622,2 mil; em 2015, 698,6 mil; em 2016, 722,1 mil; e, em 2017, 726,3 mil (BRASIL, 2019.). 
Neste contexto, podem-se apontar certas divergências doutrinárias no que diz respeito a este tema. Para Nilo Batista, conforme citado por Alice Bianchini (2014, 116), "a Lei Maria da Penha é um exemplo atual da postura retribucionista-aflitiva do movimento feminista, que encontra na punição exacerbada do agressor forma possível de combate à violência doméstica". Ou seja, a crítica traçada vai no sentido de que o agravamento da punição estatal na Lei Maria da Penha é fruto do clamor feminista pela "vingança e castigo" do homem, sendo esta solicitação atendida legislativamente sem a observância de outros métodos capazes de inibir as condutas violentas, atuando a legislação especial de proteção à mulher, juntamente com o instrumento cautelar das medidas protetivas de urgência, na expansão do direito penal e do movimento punitivista.

Porém, o grande problema de entender a Lei Maria da Penha como instrumento de "vingança e castigo" ao homem é que, desta maneira, o Direito Penal estará retrocedendo à sua primeira modalidade conhecida, a da "vingança privada", no qual o único fundamento da pena consiste na pura e simples retribuição a alguém pelo mal praticado, atuando o Estado em favor dos interesses particulares em detrimento de seus interesses públicos. Entretanto, ao direcionar a aplicação do Direito Penal à vingança privada, com a imposição de graves penas aos agressores, o Estado deixa de preocupar-se com a resolução geral de um determinado problema social, resultando em verdadeira ineficácia social dos meios punitivos.

Pode-se, assim, constatar que as normas penais, embora possam ser consideradas benéficas em países subdesenvolvidos, não podem deixar de apresentar visíveis vantagens ao fim ao qual se destinam, sob pena de sujeitar o Direito Penal ao arcaico modelo de "vingança privada".

Por outro lado, grande parte dos doutrinadores não reconhece a Lei Maria da Penha como legislação simbólica, como, por exemplo, Alice Bianchini (2014, p. 118), que, apesar de inferir que "de fato, ambas as situações (intervenção do direito penal e distanciamento da intervenção punitiva) são problemáticas", preleciona que a Lei Maria da Penha difere das demais normas punitivistas, visto que

deu um tratamento totalmente diferenciado ao conflito, na medida em que criou os Juizados da Violência Doméstica e assistencial à vítima e ao agressor (como também aos familiares e às testemunhas). Por conta disso, a atuação dos Juizados deve diferir daquela tradicionalmente legada à justiça criminal, não se limitando à apreciação das responsabilidades criminais e à distribuição de castigo.

Isto posto, percebe-se que a Lei Maria da Penha não se afigura, à primeira vista, como uma legislação meramente simbólica, na medida em que prevê a criação de juizados e delegacias especiais, programas assistenciais às partes envolvidas, promoção de estudos e pesquisas relacionadas ao tema, implementação de atendimento especializado pela polícia, promoção de programas educacionais, entre outros. Ainda, refere Bianchini (2014) que as medidas protetivas de urgência nada mais são do que procedimentos diversos da prisão cautelar, demonstrando, desta forma, que seu intuito difere da pura punição exacerbada e desmedida.

Afastado, então, o caráter meramente punitivista da Lei Maria da Penha, passar-se-á à análise cerne quanto as medidas protetivas de urgência e Lei no 13.641/2018.

Conforme já referido, verifica-se que o instituto das medidas protetivas de urgência, em verdade, cria diversos mecanismos capazes de inibir a aplicação de medidas mais gravosas ao agressor, como a prisão preventiva, utilizada até então como prima ratio nos casos de iminente perigo à integridade das vítimas de violência doméstica e familiar, através da possibilidade de aplicação de ferramentas especiais cabíveis em diferentes situações, como o afastamento do 
agressor do lar, a proibição de se aproximar da vítima, a suspensão da posse e a restrição do porte de arma de fogo, entre outras.

Por conseguinte, as medidas protetivas de urgência, embora possam apresentar determinado caráter punitivo, em virtude da restrição de determinados direitos provocados por sua decretação, não devem ser reconhecidas como sancionatórias, uma vez que sua fundamentação é exclusivamente cautelar.

Assim sendo, as medidas protetivas de urgência não são um instrumento de punição estatal, mas sim, instrumento de proteção à mulher que visa a possibilitar uma metodologia especial adequada a cada caso concreto, buscando sempre que possível a restrição de determinados direitos do agressor da forma mais proporcional possível.

Desta forma, conclui-se que as medidas protetivas de urgência, por se tratarem de medidas cautelares, que assim como as demais, buscam garantir o normal desenvolvimento do processo com a consequente eficaz aplicação do poder de punir, não podem ser reconhecidas como de natureza punitiva, tampouco, de caráter simbólico, na medida em que oriundas de legislação considerada pelo próprio Supremo Tribunal Federal como constitucional.

Embora ainda não sejam capazes de acarretar plena proteção às vítimas, devido à carência do sistema assistencial previsto pela Lei Maria da Penha, que engloba a capacitação policial, a criação de programas auxiliares e de delegacias e varas especiais, incontestável é a contribuição das medidas protetivas de urgência para a proteção das mulheres em situação de iminente perigo de violência, tanto física, quanto psicológica, sexual, patrimonial e moral, nos termos do art. $7^{\circ}$, da própria Lei no $11.340 / 2006$.

Consequentemente, as medidas protetivas de urgência se demonstram como um verdadeiro "mal necessário", uma vez que, assim como a prisão preventiva, esta medida cautelar se demonstra predisposta a incidir em situações nas quais a análise das circunstâncias exatas ainda não evidencia clareza, levando os magistrados a valerem-se da máxima de que "é melhor prevenir do que remediar" para que justifiquem a sua aplicação a determinados casos. Entretanto, é possível afirmar que mais vale "arriscar" proporcionalmente a restrição de um determinado direito do que desproporcionalmente a dignidade, a integridade e a vida de uma pessoa.

Em última observação, uma vez já examinada a Lei Maria da Penha como um todo e as medidas protetivas de urgência em apartado, conclui-se que a promulgação da Lei no 13.641/2018, que tipificou o delito de descumprimento das medidas protetivas de urgência, também não deve ser reconhecida como de caráter punitivista, tampouco simbólico, uma vez que a tipificação dada ao delito visa ao mero processamento do agressor-descumpridor das medidas protetivas de urgência, que até então seria absolvido em virtude dos apresentados entendimentos jurisprudenciais de que o descumprimento das medidas protetivas de urgência não caracterizava delito de desobediência, descrito no art. 330, do Código Penal.

Neste sentido, a promulgação da Lei em questão não aparenta incrementar nova punição à legislação de proteção à mulher, mas sim, suprir a lacuna normativa que se formava em torno desta discussão e que acarretava impunidade aos agressores que descumpriam as medidas protetivas de urgência. Ora, a elaboração de leis que visam a romper determinada impunidade instaurada no ordenamento jurídico não podem ser reconhecidas como punitivistas, uma vez que sua intenção não é a de meramente penalizar, mas sim, de estabelecer normas capazes de preencher as omissões legislativas a atos notoriamente contrários à legislação e aos interesses estatais.

Uma vez reconhecida a necessidade de implementação desta norma, há de se aferir que sua eficácia se relaciona ao fato de que além de influir como motivo segregador, a mera existência da tipificação deste delito atua como empecilho cognitivo indireto ao agressor que 
deseja reincidir contra a vítima, por saber que a concretização de sua vontade lhe renderá possível agravamento da pena final ou até mesmo o processamento por esta nova infração, diferentemente do que que ocorreria antes da promulgação desta lei e que já era sabido pelos agressores reincidentes.

Ainda, o acréscimo do art. 24-A, à Lei Maria da Penha, decorrente da promulgação da Lei no $13.641 / 2018$, encerrou a discussão que se gerava em torno da impossibilidade de decretação de prisão preventiva aos descumpridores das medidas protetivas de urgência, uma vez que havia se firmado entendimento no Superior Tribunal de Justiça de que a aplicação desta medida cautelar se fazia ilegítima em virtude da ausência de tipificação do delito e acarretava também discussão quanto à possibilidade de prisão em flagrante do agressor-descumpridor quando não houvesse outro delito sendo cometido, proporcionando, desta forma, maior eficácia na proteção à integridade e vida da mulher.

Por fim, cumpre destacar que o delito de descumprimento das medidas protetivas prevê pena igual ao do delito de desobediência a decisão judicial, descrito no art. 359, do Código Penal, o que demonstra proporcionalidade em seu apenamento e não exacerbação dos meios sancionatórios.

\section{CONSIDERAÇÕES FINAIS}

A partir das discussões empreendidas ao longo do presente estudo, constata-se que as medidas protetivas de urgência vêm demonstrando, por meio da sua aplicação no decorrer dos anos, satisfatório resultado no que diz respeito ao combate à violência de gênero, sobretudo, à erradicação da problemática relativa à reincidência delitiva, perpetrada cotidianamente pelos agressores em um ciclo de violência que por incontáveis vezes gera o resultado morte da vítima.

O termo satisfatório parece então se sobrepor ao termo eficaz, uma vez que, embora satisfatório, o instrumento cautelar não deixa de apresentar variadas incapacidades práticas, que decorrem, sem embargo, não em virtude de suas disposições e formulação, mas sim, da carência de suporte assistencial à sua aplicação, embora haja ampla previsão de mecanismos auxiliares que se demonstram escassos em sua implementação.

Uma norma marcadamente simbólica, para que se possa atenuar a incontível expansão do direito penal, deve ser extraída da legislação sempre que assim verificada, mas a Lei Maria da Penha como um todo vem se demonstrando como único mecanismo capaz de garantir superior proteção às vítimas de violência doméstica e familiar no país, motivo pelo qual sua extinção se demonstraria como indirimível retrocesso legal ao resguardo de direitos conquistados pelas mulheres durante hedionda e dolorosa batalha histórica enfrentada por elas desde os primórdios da humanidade, motivo pelo qual a legislação de proteção à mulher como um todo não pode ser considerada como exclusivamente simbólica.

Para que se possa então garantir que a eficácia das medidas protetivas de urgência se afaste cada vez mais do polo do mero simbolismo penal é necessário que determinados preceitos descritos na Lei Maria da Penha recebam maior acolhimento por parte do Estado, como a criação de Delegacias da Mulher, a capacitação dos policiais militares e a criação de centros de atendimento às vítimas. Deste modo, as medidas protetivas de urgência poderão encontrar cada vez mais amparo nos preceitos constituintes da rede de proteção à mulher e eficácia em sua aplicação. 


\section{REFERÊNCIAS}

BANDEIRA, Regina. CNJ divulga dados do Judiciário sobre violência contra a mulher. 25 de outubro de 2017. [Brasília]. Disponível em: <http://www.cnj.jus.br/noticias/c nj/85640cnj-publica-dados-sobre-violencia-contra-a-mulher-no-judiciario $>$. Acesso em: 14 nov. 2020.

BASTOS, Tatiana Barreira. Violência doméstica e familiar contra a mulher: análise da Lei Maria da Penha (Lei no 11.340/2006): um diálogo entre a teoria e a prática. 2. ed. Porto Alegre: Verbo Jurídico, 2013.

BIAGI, Sandra Fernandes. Lei Maria da Penha: a aplicabilidade das medidas protetivas de urgência como instrumento de prevenção e combate à reincidência. Trabalho de Conclusão de Curso de Especialização (Especialista em Educação) - Programa de Pós-Graduação em Gestão de Políticas Públicas em Gênero e Raça-GPPGeR, Faculdade de Educação, Universidade de Brasília, DF, 2014. Disponível em: <http://bdm.unb.br/bitstream/10483/13099/1/2014_ SandraFernandesBiagi.pdf $>$. Acesso em: 15 nov. 2020.

BIANCHINI, Alice. Lei Maria da Penha: Lei 11.340/2006: aspectos assistenciais, protetivos e criminais da violência de gênero. 2. ed. São Paulo: Saraiva, 2014.

BRASIL. Decreto-Lei no 2.848, de 7 de dezembro de 1940. Código Penal. Disponível em: <http://www.planalto.gov.br/ccivil_03/decreto-lei/Del2848compilado.htm>. Acesso em: 15 nov. 2020.

BRASIL. Decreto-Lei no 3.689, de 3 de outubro de 1941. Código de Processo Penal. Disponível em: <http://www.planalto.gov.br/ccivil_03/decreto-lei/Del3689.htm>. Acesso em: 15 de nov. 2018 .

BRASIL. Superior Tribunal de Justiça. Recurso Especial no 1.387.885-MG. Recorrente: Juliomar Vieira Martins. Recorrido: Ministério Público. Relator: Min. Jorge Mussi. Brasília, o5 de dezembro de 2013. Disponível em: < https://ww2.stj.jus.br/processo/ revista $/$ documento $/$ mediado $/$ ?componente $=$ MON\&sequencial $=32956077 \&$ num

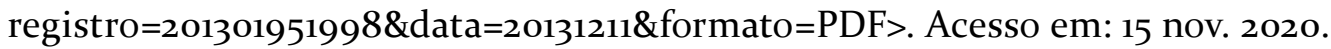

BRASIL. Lei no 9.099, de 26 de setembro de 1995. Dispõe sobre os Juizados Especiais Cíveis e Criminais e dá outras providências. Disponível em: <http://www.planalto.gov.br/ccivil_03/ leis/L9099.htm>. Acesso em: 15 de nov. 2020.

BRASIL. Lei no 10.886, de 17 de junho de 2004. Acrescenta parágrafos ao art. 129 do DecretoLei no 2.848 , de 7 de dezembro de 1940 - Código Penal, criando o tipo especial denominado "violência doméstica". Disponível em: <http://www.planalto.gov.br/ccivil_03/_Ato20042006/2004/Lei/L1o.886.htm>. Acesso em: 15 nov. 2020.

BRASIL. Lei no 11.313, de 28 de junho de 2oo6. Altera os arts. 6o e 61 da Lei no 9.099, de 26 de setembro de 1995, e o art. 2º da Lei no 10.259, de 12 de julho de 2001, pertinentes à competência dos Juizados Especiais Criminais, no âmbito da Justiça Estadual e da Justiça Federal. Disponível em: <http://www.planalto.gov.br/ccivil_03/_Ato2004-2006/2006/Lei/L11313.htm>. Acesso em: 15 nov. 2020. 
BRASIL. Lei no 11.340, de 7 de agosto de 2oo6. Cria mecanismos para coibir a violência doméstica e familiar contra a mulher, nos termos do § 80 do art. 226 da Constituição Federal, da Convenção sobre a Eliminação de Todas as Formas de Discriminação contra as Mulheres e da Convenção Interamericana para Prevenir, Punir e Erradicar a Violência contra a Mulher; dispõe sobre a criação dos Juizados de Violência Doméstica e Familiar contra a Mulher; altera o Código de Processo Penal, o Código Penal e a Lei de Execução Penal; e dá outras providências. Disponível em: <http://www.planalto.gov.br/ccivil_03/_ato2004-2006/2006/lei/l11340.htm>. Acesso em: 15 nov. 2020.

BRASIL. Lei no 13.641, de 3 de abril de 2o18. Altera a Lei no 11.340, de 7 de agosto de 2006 (Lei Maria da Penha), para tipificar o crime de descumprimento de medidas protetivas de urgência. Disponível em: < http://www.planalto.gov.br/ccivil_03/_Ato2015-2018/2018/Lei/L13641.htm>. Acesso em: 15 nov. 2020.

BRASIL. Superior Tribunal de Justiça. Súmula no 536. A suspensão condicional do processo e a transação penal não se aplicam na hipótese de delitos sujeitos ao rito da Lei Maria da Penha. Disponível em: < http://www.stj.jus.br/docs_internet/SumulasSTJ.pdf>.Acesso em: 15 nov. 2020.

BRASIL. Levantamento Nacional de Informações Penitenciárias - Período de Julho a Dezembro de 2019. Brasília: Departamento Penitenciário Nacional, 2020.

CALLEGARI, André Luis; WERMUTH, Maiquel Ângelo Dezordi. Sistema penal e política criminal. Porto Alegre: Livraria do Advogado Editora, 2010.

DIAS, Maria Berenice. A Lei Maria da Penha na justiça: a efetividade da Lei 11.340/2006 de combate à violência doméstica e familiar contra a mulher. 3. ed. rev., atual. e ampl. São Paulo: Editora Revista dos Tribunais, 2010.

FÓRUM BRASILEIRO DE SEGURANÇA PÚBLICA. Atlas da violência 2oro: principais resultados, 2020. Disponível em: https://www.ipea.gov.br/atlasviolencia/arquivos/artigos/5929atlasviolencia202orelatoriofinalcorrigido.pdf. Acesso em: 8 jan. 2021.

GONÇALVES, José Aldyr. O fim do patriarcalismo. or de novembro de 2009. [S.l]. Disponível em: <https://www.webartigos.com/artigos/o-fim-do-patriarcalismo/27353>. Acesso em: 14 nov. 2020 .

JESUS, Damásio de. Violência contra a mulher: aspectos criminais da Lei n. 11.340/2006. 2. ed. São Paulo: Saraiva, 2015.

MONTENEGRO, Manuel Carlos. Justiça concede 236 mil medidas protetivas em 2017. 22 de junho de 2018. [Brasília]. Disponível em: <http://www.cnj.jus.br/noticias/cnj/8 7047-justicaconcede-236-mil-medidas-protetivas-em-2017>. Acesso em: 14 nov. 2020.

PARANÁ. Tribunal de Justiça. Apelação crime no 2011.oo13666-o, da 1 á Turma Recursal. Apelante: Vilmar Capeletti Boff. Apelado: Ministério Público. Relator: Mychelle Pacheco Cintra. Curitiba, 19 de abril de 2012. Disponível em: < http://portal.tjpr.jus.br/ jurisprudencia/j/32011001366600201204271/Ac\%C3\%B3rd\% $3 \% \mathrm{C}_{3} \% \mathrm{O}-20110013666-\mathrm{o}>$. Acesso em: 15 nov. 2020. 
RIO DE JANEIRO. Tribunal de Justiça. Apelação crime no oooo165-27.2011.8.19.0o44, da 6o Câmara Criminal. Apelante: Francisco de Assis Filho. Apelado: Ministério Público. Relator: Des. Rosita Maria de Oliveira Netto. Rio de Janeiro, 11 de dezembro de 2012. Disponível em: <http://www1.tjrj.jus.br/gedcacheweb/default.

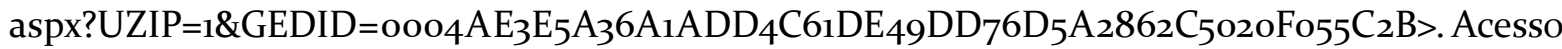
em: 15 nov. 2020.

RIO GRANDE DO SUL. Tribunal de Justiça. Apelação crime no $\mathbf{7 0 0 7 7 9 2 8}_{554}$, da $3^{\text {a }}$ Câmara Criminal. Apelante: Carlos Doris da Silva. Apelado: Ministério Público. Relator: Des. Ingo Wolfgang Sarlet. Porto Alegre, 15 de agosto de 2018. Disponível em: < https://www.tjrs.jus. $\mathrm{br} /$ novo/buscas-solr/?aba=jurisprudencia\&q=\&conteudo_busca=ementa_completa\#main_ res_juris>. Acesso em: 15 nov. 2020.

RIO GRANDE DO SUL. Tribunal de Justiça. Apelação crime no 71003939295, da Turma Recursal Criminal, Turmas Recursais. Apelante: Ministério Público. Apelado: Márcio André Trente. Relator: Eduardo Ernesto Lucas Almada. Porto Alegre, 17 de dezembro de 2012. Disponível em: < https://www.tjrs.jus.br/novo/buscas-solr/?aba=jurisprudencia\&q=\&con teudo_busca=ementa_completa\#main_res_juris>. Acesso em: 15 nov. 2020.

WAISELFISZ, Julio Jacobo. Mapa da violência 2015: homicídio de mulheres no Brasil. 1. ed. Brasília, DF: Flacso Brasil, 2015. Disponível em: <https:/www.mapadaviolencia.org.br/ pdf2015/MapaViolencia_2015_mulheres.pdf>. Acesso em: 14 nov. 2020.

WERMUTH, Maiquel Ângelo Dezordi; NIELSSON, Joice Graciele. O campo como espaço da exceção: uma análise da produção da vida nua feminina nos lares brasileiros à luz da biopolítica. 2016. Universidade Federal da Paraíba, programa de pós-graduação em ciências jurídicas, João Pessoa, PB. v. 15. n. 30. Disponível em: <http://www.periodicos.u fpb.br/ index.php/primafacie/article/view/33084>. Acesso em: 14 nov. 2020. 